\title{
Insecticidal and inhibitory effects of Meliaceae and Asteraceae extracts to silverleaf whitefly
}

\author{
Edson Luiz L Baldin ${ }^{1} \mathbb{D}$; Eunice Cláudia Schlick-Souza ${ }^{1} \mathbb{D}$; Muriel CE Soares ${ }^{1} \mathbb{D}$; Norberto P Lopes ${ }^{2} \mathbb{D}$; João \\ Luis C Lopes ${ }^{2} \mathbb{D}$; Paulo César Bogorni ${ }^{3} \mathbb{D}$; José D Vendramim ${ }^{3 \mathbb{D}}$
}

${ }^{1}$ Universidade Estadual Paulista (UNESP), Botucatu-SP, Brasil; edson.baldin@unesp.br (author for correspondence); euniceschlick@ hotmail.com; mu_emanoeli@hotmail.com; ${ }^{2}$ Universidade de São Paulo (USP), Ribeirão Preto-SP, Brasil; npelopes@fcfrp.usp.br; joaoluis@ usp.br; ${ }^{3}$ Escola Superior de Agricultura "Luiz de Queiroz" (ESALQ), Piracicaba-SP, Brasil; bogorni@biopartner.agr.br; jdvendra@usp.br

\begin{abstract}
Bemisia tabaci (Hemiptera: Aleyrodidae) is a polyphagous insect that causes direct and indirect damage on tomato. Spraying with synthetic insecticides is one of the main control tools for the whitefly; however, the abusive use of this tool can impact the environment and human beings. In this study we evaluated the bioactivity of extracts from plant species from Asteraceae and Meliaceae families on $B$. tabaci biotype $\mathrm{B}$ in tomato. A preliminary bioassay evaluated the effects of the extracts at $2 \%(\mathrm{w} / \mathrm{v})$ on infestation and oviposition of this whitefly. Then, the nymphicidal and ovicidal effects of the chloroformic extract of Trichilia pallida - TP-Cl at six concentrations were performed. Finally, the TP-Cl $\mathrm{LC}_{50}$ was estimated. All extracts were repellent to the whitefly, except that ones from $T$. pallida (ethanolic) and Melia azedarach (hexanic), considered neutral at $24 \mathrm{~h}$. All the extracts caused deterrence of oviposition. All concentrations of TP-Cl revealed nymphicidal activity and the highest ones provided the lowest egg viability averages. The estimated $\mathrm{LC}_{50}$ was $0.0955 \%$. These results provide evidence for the potential of the extracts to be used as alternative control agents of $B$. tabaci biotype B in tomatoes.
\end{abstract}

Keywords: Bemisia tabaci, botanical pesticide, allelochemical, alternative control.

\section{RESUMO}

Efeitos inseticida e inibitório de extratos de Meliaceae e Asteraceae sobre a mosca-branca

Bemisia tabaci (Hemiptera: Aleyrodidae) é um inseto polífago que causa danos diretos e indiretos na cultura do tomateiro. A pulverização com inseticidas sintéticos é um dos principais métodos de controle, porém, o uso abusivo dessa ferramenta pode impactar o ambiente e os seres humanos. Este estudo avaliou a bioatividade de extratos de plantas das famílias Asteraceae e Meliaceae sobre B. tabaci biótipo B em tomateiro. Um ensaio preliminar avaliou os efeitos dos extratos a $2 \%(\mathrm{p} / \mathrm{v})$ sobre a infestação e oviposição dessa mosca-branca. Os efeitos ninficida e ovicida do extrato clorofórmico de Trichilia pallida - TP-Cl em seis concentrações foram avaliados. Finalmente, a TP-Cl $\mathrm{CL}_{50}$ foi estimada. Todos os extratos foram repelentes para a mosca-branca, com exceção de $T$. pallida (etanólico) e Melia azedarach (hexânico), considerados neutros em 24 h. Todos os extratos causaram deterrência para oviposição. Todas as concentrações de TP-Cl apresentaram atividade ninficida e as maiores promoveram as menores médias de viabilidade de ovos. $\mathrm{A} \mathrm{CL}_{50}$ foi de $0,0955 \%$. Os resultados evidenciaram o potencial dos extratos para serem usados como agentes alternativos de controle de B. tabaci biótipo B em tomateiro.

Keywords: Bemisia tabaci, inseticida botânico, aleloquímico, controle alternativo.

Received on October 25, 2019; accepted on July 9, 2020

$\mathrm{N}^{a}$ ative to southern Asia, the whitefly Bemisia tabaci is a polyphagous pest present in a large number of plants, including the tomato Solanum lycopersicum (Srinivasan et al., 2012). Currently, B. tabaci is considered, by some authors, a complex of cryptic species, including the B-biotype called MEAM1 (De Barro et al., 2011). In this study, the older nomenclature still employed by many researchers will be used.

The productivity losses in tomato crops due to $B$. tabaci biotype B are mainly related to the geminiviruses transmission (Inoue-Nagata et al., 2016; Rojas et al., 2018). Infected plants present chlorotic spots on the leaves, mottling and mosaic, in addition to low flowering and reduction of ${ }^{\circ}$ Brix in fruits (Hanssen et al., 2010). Direct damage occurs due to the constant suction of the sap by the insect, inducing irregular ripening of the fruits; indirect damage is favored by the excretion of honeydew, which can promote growth of black sooty mold fungi (Capnodium sp.), interfering with photosynthesis and also favoring viral infection (Firdaus et al., 2012).

Management programs for $B$. tabaci biotype $\mathrm{B}$ include mostly the use of synthetic insecticides (Shadmany et 
al., 2015). However, populations of B. tabaci from different origins have revealed a high degree of resistance to various groups of insecticides (Dângelo et al., 2018), limiting the use of these products in the long term.

Thus, several studies have been carried out in search of alternative, efficient and safer practices against the whitefly, with emphasis on products of botanical origin (Baldin et al., 2015).

Species from the Meliaceae family exhibit bioactivity against $B$. tabaci biotype B (Bezerra-Silva et al., 2012) and have already been documented for Azadirachta indica (Musabyimana et al., 2001) and for species of the genus Trichilia (Baldin et al., 2007a) and Melia (Abou-Fakhr Hammad et al., 2014). Several species from the Asteraceae family are found in cerrado and rupestrian regions (Grael et al., 2010). They have great genetic variability and, consequently, diversity with the formation of high levels of lactones, triterpenes and flavonoids (Grael et al., 2010).

Although the bioactivity of asteraceous extracts of the genus Lychnophora and Mikania on whiteflies has not yet been documented, its insecticidal potential has already been reported on other species of pest insects (Tavares et al., 2009). Due to the high damage potential of this pest on tomato and the lack of control by less aggressive control methods in relation to the use of synthetic insecticides, this study evaluated the bioactivity of organic extracts of Meliaceae and Asteraceae species on B. tabaci biotype B.

\section{MATERIAL AND METHODS}

\section{Bemisia tabaci biotype $B$ rearing}

Insects used in this study came from the existing colony at the Department of Crop Protection of the FCA/UNESP, Botucatu Campus, SP, Brazil. Insects were kept in a screen cage $(3.0 \times 2.5 \times$ $2.0 \mathrm{~m}$ ) covered with plastic sheeting and shade cloth; the lateral and frontal parts were protected with white anti-aphid screens, allowing adequate luminosity and ventilation and preventing the exit and entrance of insects. To maintain the colony, pots (10 L) containing cabbage Brassica olearacea var. acephala were placed in the cage. A molecular characterization of the insects was performed according to De Barro et al. (2003) to confirm the biotype B strain used in the current study.

\section{Collecting plants}

Leaves of Trichilia casaretti, Trichilia catigua, Trichilia clausenii, Trichilia elegans, Trichilia pallida and Melia azedarach were collected from trees located on the "Luiz de Queiroz" College of Agriculture Campus in Piracicaba, São Paulo, Brazil. Their corresponding voucher specimens (ESA81824, ESA81285, ESA81289, ESA81287, ESA81288, not provided, respectively) were deposited at the Herbarium in the same institution. Leaves of Asteraceae species Mikania glomerata, Lychnophora ericoides, Lychnophora granmongolense and Lychnophora salicifolia were collected in cerrado areas in Furnas, Minas Gerais, Brazil. Their respective voucher specimens are: not provided, UEC 96982, not provided and UEC 174942. The almonds of $A$. indica were purchased from the local market (Nim Brazil Inc., Patos de Minas, MG, Brazil).

\section{Preparation of plant extracts}

Leaves of $T$. casaretti, T. catigua, T. clausenii, T. elegans, T. pallida, $M$. azedarach, $M$. glomerata, $L$. ericoides, L. granmongolense and $L$. salicifolia and almonds of $A$. indica were dehydrated in an oven at $40^{\circ} \mathrm{C}$ for $48 \mathrm{~h}$ and ground into powders in a knife mill. The resulting powders were kept in hermetically closed glass flasks. Organic extracts from each part of the plant were obtained with the solvents hexane, chloroform and ethanol. To obtain the extracts, the plant powders were subjected to a Soxhlet extraction system. Samples of powder of each structure were placed into a number five filter paper cartridge (Soxhlet) along with solvents. The extraction endpoint was reached when the solvent showed no color after passing through the sample. This procedure was repeated until completion of extraction of the total sample mass. The extracts were concentrated in a swivel evaporator at $40^{\circ} \mathrm{C}$ at low pressure, thereby obtaining the extract yields. The extracts were stored in dark glass flasks and kept in a laminar flow cabinet to allow the complete evaporation of the solvents (Bezerra-Silva et al., 2012).

\section{Screening for selection of plant species and most suitable solvent}

Initially, tomato seeds (cv. Santa Clara) were sown in expanded polyethylene trays ( 72 cells); after 25 days of planting, the seedlings were transplanted to $2.5 \mathrm{~L}$ pots containing soil and Plantmax $\mathrm{HT}^{\circledR}$ substrate (Eucatex Inc., Botucatu, SP, Brazil) in a ratio of $1: 1$, offering all needed conditions for the crop (Raij et al., 1997).

After ten days following transplantation, the plants had three leaflets (upper, middle and lower third) marked with a glitter tube, just to identify the leaflets that would be sprayed with the extracts. These leaflets were later sprayed on abaxial face with leaves extracts of T. casaretti, T. catigua, T. clausenii, T. elegans, T. pallida, M. azedarach, M. glomerata, L. ericoides, L. granmongolense and L. salicifolia and almonds extract of $A$. indica at $2 \%$ $(\mathrm{w} / \mathrm{v})$, based on preliminary tests, until the extract began to run off $(\approx 1 \mathrm{~mL})$ with the aid of a microatomizer coupled to a pneumatic pump at $0.5 \mathrm{kgf} \mathrm{cm}^{-2}$. Pots containing the treatments and the control (distilled water) were placed randomly in a circle inside a metal cage $(3.0 \times 2.5 \times 2.5 \mathrm{~m})$, where whitefly adults were released on the ground and in the center, in a proportion of 50 couples per pot. The evaluations were conducted at 24 and $48 \mathrm{~h}$ after infestation, counting with the help of a mirror the number of adults present on the abaxial surface of the previously marked leaflets. To obtain the adult inhibition index (II), the following formula was used: II $=2 \mathrm{~T} /(\mathrm{T}+\mathrm{C})$, where $\mathrm{T}=$ number of insects or eggs counted in the selected leaflet and $\mathrm{C}=$ number of insects or eggs counted in the control. Based on the indexes and standard deviations obtained, the classification intervals (CI) for the treatment averages were determined using the formula: $\mathrm{CI}=[(1$ $\pm \mathrm{t}(\mathrm{n}-1 ; \infty=0.05)) \times(\mathrm{SD} / \mathrm{n} 1 / 2)]$; where $\mathrm{t}=$ value of Student's t test at $5 \%$ 
probability; $\mathrm{SD}=$ standard deviation; $\mathrm{n}$ $=$ number of replications. The treatments were considered neutral when the value of their indexes was included within the calculated $\mathrm{CI}(\mathrm{CI}<\mathrm{II}<\mathrm{CIs})$, were inhibitory when the values remained lower than the calculated CI $(\mathrm{II}<\mathrm{CIi})$ and were stimulating when the values were above the calculated CI (II>CIs) (Silva et al., 2012).

After the last count of adults (48 h), the labeled leaflets were removed from the plants and taken to the laboratory, where the number of eggs $/ \mathrm{cm}^{2}$ was counted using a stereomicroscope (40x) for the posterior calculation of oviposition preference index (OPI). The following formula was used: OPI $=[(\mathrm{T}-\mathrm{C}) /(\mathrm{T}+\mathrm{C})] \times 100$, where $\mathrm{T}=$ extract evaluated and $\mathrm{C}=$ control. OPI ranges from +100 for very stimulating (S), 0 for neutral (N) up to -100 for very deterrent (D) (Baldin et al., 2005). Each cage containing pulverized plants and insects was a replicate and a total of five were used following a randomized block design.

Bioactivity and estimated $\mathrm{LC}_{50}$ from $T$. pallida - chloroform

With the aim of determining a suitable concentration for the use of the extracts in future trials, an experiment was carried out with chloroform extract based on the leaves of $T$. pallida (TP$\mathrm{Cl}$ ). The decision to test the extract in chloroform was made due to the better efficiency indexes obtained in another research (Gonçalves-Gervásio \& Vendramim, 2004) and because this fraction stood out as producing a low rate of infestation by adults ( $48 \mathrm{~h}$ ) and low oviposition in the previous trial.

Following 30 days after transplantation, the 'IAC-Santa Clara' tomato plants were conditioned inside the research colony for infestation with whitefly adults for $24 \mathrm{~h}$. After this period, the plants were removed from the cage and the insects removed from the plants. Sixteen plants were separated for one bioassay with eggs and 16 for another bioassay with nymphs. Then, three leaflets of each plant containing 30 individuals (second instar) were sprayed to the point of runoff $(\approx 1 \mathrm{~mL})$ with the extracts at $0.1,0.5,1.0,1.5,2.0$ and $3.0 \%(\mathrm{w} / \mathrm{v})$ using a microatomizer coupled to a pneumatic pump at $0.5 \mathrm{kgf}$ $\mathrm{cm}^{-2}$. The remaining eggs and nymphs were removed with a cotton swab. For controls, distilled water and acetone (solvent used to dilute the extract) were used. Each leaflet represented a replicate (six/treatment) for the two life stages of the insect, following a completely randomized design. After completely drying, the pulverized leaflets were placed in glass tubes $(8$ $\times 2 \mathrm{~cm}$ ) containing deionized water and were kept in the laboratory $(\mathrm{T}=$ $25 \pm 2{ }^{\circ} \mathrm{C}$; R.H. $=60 \pm 10 \%$; 14:10-L:D). The whitefly eggs and nymphs were evaluated during ten days after the applications to obtain the mortality of nymphs, viability of eggs and period of egg incubation. The $\mathrm{LC}_{50}$ was estimated only for nymphs, considering the results of the evaluations after $24 \mathrm{~h}$ of the extract applications.

\section{Statistical analysis}

The obtained data were submitted to analysis of variance using the F-test, and the means were compared using Scott Knott's test at the 5\% probability level. Normality was verified using the Shapiro-Wilk test, and homogeneity was analyzed using Levene's test. When the F-test was significant, the means were compared using SAS 9.2 software (SAS Institute 2001). Data related to the percentages of mortality were transformed to arc sine $(\mathrm{x}+0.5)^{1 / 2}$. For the estimation of the $\mathrm{LC}_{50}$, a probit analysis was performed using the Polo Plus program (LeOra Software, 2003).

\section{RESULTS AND DISCUSSION}

The yield of the extracts varied according to the structures of the plant species and the solvent used. The hexanic extract of almonds from $A$. indica stood out among the others with a $38.49 \%$ yield. The other extracts presented yields lower than $10 \%$. In general, the fractions in hexane provided the lowest yield indexes of extracts, except for materials from $T$. pallida and $A$. indica. The extracts in ethanol presented higher yield rates (over 5\%) from T. catigua, T. clausenii, T. elegans and $M$. azedarach, while chloroformic fractions showed higher yields (up to 3\%) for T. clausenii, $T$. casaretti, $M$. azedarach, L. salicifolia, L. granmongolense and $A$. indica.

Screening for selection of plant species and most suitable solvent

For the infestation tests, $24 \mathrm{~h}$ after spraying, the lowest insect leaflet average was observed for $A$. indica hexane (AI-Hx) (1.5 individuals), $A$. indica - chloroform (AI-Cl) (3.1), $M$. glomerata - ethanol (MG-Et) (4.7), T. catigua - hexane (TCat-Hx) (4.7), L. ericoides - ethanol (LE-Et) (5.7), $M$. glomerata - chloroform (MG-Cl) (5.7), T. clausenii - ethanol (TCla-Et) (5.9), L. salicifolia - ethanol (LS-Et) (6.3), L. granmongolense - chloroform (LG-Cl) (6.6), T. casaretti - ethanol (TCas-Et) (6.6), M. glomerata - hexane (MG-Hx) (6.9), L. granmogolense - hexane (LGHx) (6.9), T. clausenii - hexane (TClaHx) (7.1), M. azedarach - ethanol (MAEt) (7.7), T. pallida - hexane (TP-Hx) (7.8), L. salicifolia - hexane (LS-Hx) (8.0), T. pallida - chloroform (TP-Cl) (8.9), T. elegans - chloroform (TECl) (8.9), T. elegans - ethanol (TE-Et) (9.3), A. indica - ethanol (AI-Et) (9.9), T. casaretti - chloroform (TCas-Cl) (10.4), T. catigua - chloroform (TCatCl) (10.6) $(F=2.08 ; \mathrm{df}=33,132 ; P=$ $0.0018)$, which differed from the control for which the highest mean was found (27.4) and the other treatments.

Forty eight hours after the spraying, the lowest average number of insects was observed in A. indica - chloroform (AI-Cl) (1.3), A. indica - hexane (AI-Hx) (1.7), T. catigua - hexane (TCat-Hx) (4.0), T. clausenii - ethanol (TCla- Et) (4.7), L. granmongolense - chloroform (LG-Cl) (4.8), M. glomerata - ethanol (MG-Et) (5.0), L. granmongolense - hexane (LG-Hx) (5.1), M. glomerata - chroloform (MGCl) (5.3), L. salicifolia - ethanol (LS-Et) (5.3), T. casaretti - ethanol (TCas-Et) (5.7), M. azedarach - ethanol (MA-Et) (5.8), T. pallida - chloroform (TP-Cl) (6.0), T. pallida - hexane (TP-Hx) (6.4), L. ericoides - ethanol (LE-Et) (6.6), $M$. glomerata - hexane (MG-Hx) (7.0), T. elegans - chloroform (TE-Cl) (7.8), $T$. catigua-chloroform (TCat-Cl) (8.2), T. clausenii-chloroform (TCla-Cl) (8.5), T. clausenii - hexane (TCla-Hx) (9.3), T. elegans - ethanol (TE-Et) (9.5), L. 
Table 1. Mean ( \pm SE) of adults of Bemisia tabaci biotype B in tomato leaflets sprayed with different plant extracts after 24 and $48 \mathrm{~h}$ of infestation and mean $( \pm \mathrm{SE})$ of eggs per $\mathrm{cm}^{2} 48 \mathrm{~h}$ after infestation as well as oviposition preference index, and classification of treatments. $\left(\mathrm{T}=25 \pm 2^{\circ} \mathrm{C}\right.$; R.H. $=65 \pm 10 \%$; photoperiod: $\left.14 \mathrm{~h}\right)$. Botucatu, UNESP, 2012.

\begin{tabular}{|c|c|c|c|c|c|}
\hline \multirow{2}{*}{ Extract $^{1}$} & \multicolumn{2}{|c|}{ Number of adults } & \multirow{2}{*}{$\begin{array}{l}\text { Number of eggs/ } \\
\text { cm }^{2} \text { after } 48 \mathrm{~h}\end{array}$} & \multirow{2}{*}{$\mathrm{OPI}^{3}( \pm \mathrm{SE})$} & \multirow{2}{*}{ Classification } \\
\hline & $24 \mathrm{~h}$ & $48 \mathrm{~h}$ & & & \\
\hline Distilled water & $27.4 \pm 3.89 \mathrm{a}$ & $26.3 \pm 1.28 \mathrm{a}$ & $22.7 \pm 4.5 \mathrm{a}$ & $0.0 \pm 10.69$ & $\mathrm{~N}$ \\
\hline Melia azedarach-Hx & $17.3 \pm 4.4 \mathrm{a}$ & $18.0 \pm 4.2 \mathrm{a}$ & $13.2 \pm 3.9 \mathrm{~b}$ & $-26.5 \pm 10.7$ & $\mathrm{D}$ \\
\hline Trichilia elegans- $\mathrm{Hx}$ & $19.1 \pm 10.6 \mathrm{a}$ & $16.7 \pm 6.9 \mathrm{a}$ & $11.9 \pm 5.8 \mathrm{~b}$ & $-31.1 \pm 10.7$ & $\mathrm{D}$ \\
\hline T. casaretti-Cl & $10.4 \pm 2.2 b$ & $13.3 \pm 1.7 \mathrm{a}$ & $11.0 \pm 1.7 \mathrm{~b}$ & $-34.7 \pm 10.7$ & $\mathrm{D}$ \\
\hline M. azedarach-Cl & $15.3 \pm 5.6 \mathrm{a}$ & $12.9 \pm 4.2 \mathrm{a}$ & $10.6 \pm 2.7 \mathrm{~b}$ & $-36.4 \pm 10.7$ & $\mathrm{D}$ \\
\hline T. catigua-Et & $14.1 \pm 2.2 \mathrm{a}$ & $12.9 \pm 2.2 \mathrm{a}$ & $10.5 \pm 2.1 \mathrm{~b}$ & $-36.9 \pm 10.7$ & $\mathrm{D}$ \\
\hline Lychnophora salicifolia-Cl & $14.0 \pm 4.5 \mathrm{a}$ & $16.5 \pm 5.7 \mathrm{a}$ & $10.1 \pm 1.9 \mathrm{~b}$ & $-38.3 \pm 10.7$ & $\mathrm{D}$ \\
\hline L. ericoides $-\mathrm{Hx}$ & $13.7 \pm 3.5 \mathrm{a}$ & $12.3 \pm 4.1 \mathrm{a}$ & $9.9 \pm 3.3 b$ & $-39.5 \pm 10.7$ & $\mathrm{D}$ \\
\hline T. pallida-Et & $18.9 \pm 4.9 \mathrm{a}$ & $10.0 \pm 4.6 \mathrm{~b}$ & $8.2 \pm 4.2 \mathrm{c}$ & $-47.0 \pm 10.7$ & $\mathrm{D}$ \\
\hline T. clausenii-Et & $5.9 \pm 1.7 b$ & $4.7 \pm 1.3 \mathrm{~b}$ & $8.1 \pm 3.7 \mathrm{c}$ & $-47.6 \pm 10.7$ & $\mathrm{D}$ \\
\hline Azadirachta indica-Et & $9.9 \pm 5.4 \mathrm{~b}$ & $11.7 \pm 6.8 \mathrm{a}$ & $7.9 \pm 4.9 \mathrm{c}$ & $-48.3 \pm 10.7$ & $\mathrm{D}$ \\
\hline T. elegans $-\mathrm{Cl}$ & $8.9 \pm 1.9 b$ & $7.8 \pm 2.0 \mathrm{~b}$ & $7.9 \pm 1.8 \mathrm{c}$ & $-48.6 \pm 10.7$ & $\mathrm{D}$ \\
\hline T. catigua- $\mathrm{Cl}$ & $10.6 \pm 4.1 \mathrm{~b}$ & $8.2 \pm 3.3 \mathrm{~b}$ & $7.5 \pm 4.7 \mathrm{c}$ & $-50.2 \pm 10.7$ & $\mathrm{D}$ \\
\hline M. glomerata-Hx & $6.9 \pm 2.9 \mathrm{~b}$ & $7.0 \pm 3.6 \mathrm{~b}$ & $7.4 \pm 1.2 \mathrm{c}$ & $-50.9 \pm 10.7$ & $\mathrm{D}$ \\
\hline L. ericoides $-\mathrm{Cl}$ & $12.3 \pm 5.4 \mathrm{a}$ & $12.8 \pm 4.5 \mathrm{a}$ & $7.3 \pm 2.9 \mathrm{c}$ & $-51.2 \pm 10.7$ & $\mathrm{D}$ \\
\hline L. granmongolense-Et & $13.3 \pm 4.8 \mathrm{a}$ & $9.9 \pm 3.7 \mathrm{~b}$ & $6.8 \pm 1.0 \mathrm{c}$ & $-53.9 \pm 10.7$ & $\mathrm{D}$ \\
\hline T. elegans-Et & $9.3 \pm 2.7 b$ & $9.5 \pm 1.7 \mathrm{~b}$ & $6.6 \pm 1.9 \mathrm{c}$ & $-55.0 \pm 10.7$ & $\mathrm{D}$ \\
\hline M. glomerata- $\mathrm{Cl}$ & $5.7 \pm 1.6 b$ & $5.3 \pm 1.1 \mathrm{~b}$ & $6.3 \pm 1.9 \mathrm{c}$ & $-56.4 \pm 10.7$ & $\mathrm{D}$ \\
\hline T. clausenii-Hx & $7.1 \pm 4.1 \mathrm{~b}$ & $9.3 \pm 2.8 \mathrm{~b}$ & $6.3 \pm 1.7 \mathrm{c}$ & $-56.8 \pm 10.7$ & $\mathrm{D}$ \\
\hline T. clausenii- $\mathrm{Cl}$ & $12.3 \pm 3.3 \mathrm{a}$ & $8.5 \pm 3.0 \mathrm{~b}$ & $5.5 \pm 1.9 \mathrm{c}$ & $-60.9 \pm 10.7$ & $\mathrm{D}$ \\
\hline M. azedarach-Et & $7.7 \pm 3.1 \mathrm{~b}$ & $5.8 \pm 2.3 b$ & $5.5 \pm 1.5 \mathrm{c}$ & $-60.9 \pm 10.7$ & $\mathrm{D}$ \\
\hline T. pallida-Hx & $7.8 \pm 3.6 \mathrm{~b}$ & $6.4 \pm 3.8 \mathrm{~b}$ & $5.0 \pm 2.8 \mathrm{c}$ & $-63.9 \pm 10.7$ & $\mathrm{D}$ \\
\hline L. salicifolia-Hx & $8.0 \pm 2.7 \mathrm{~b}$ & $10.7 \pm 3.3 \mathrm{a}$ & $5.0 \pm 2.5 \mathrm{c}$ & $-63.9 \pm 10.7$ & $\mathrm{D}$ \\
\hline T. casaretti-Hx & $11.7 \pm 3.4 \mathrm{a}$ & $12.3 \pm 4.9 \mathrm{a}$ & $5.0 \pm 1.5 \mathrm{c}$ & $-63.9 \pm 10.7$ & $\mathrm{D}$ \\
\hline L. granmongolense- $\mathrm{Cl}$ & $6.6 \pm 1.6 \mathrm{~b}$ & $4.8 \pm 1.2 \mathrm{~b}$ & $4.8 \pm 1.5 \mathrm{c}$ & $-65.1 \pm 10.7$ & $\mathrm{D}$ \\
\hline T. pallida-Cl & $8.9 \pm 2.0 \mathrm{~b}$ & $6.0 \pm 1.7 \mathrm{~b}$ & $4.8 \pm 0.9 \mathrm{c}$ & $-65.1 \pm 10.7$ & $\mathrm{D}$ \\
\hline T. casaretti-Et & $6.6 \pm 1.3 b$ & $5.7 \pm 1.6 \mathrm{~b}$ & $4.5 \pm 0.9 \mathrm{c}$ & $-67.1 \pm 10.7$ & $\mathrm{D}$ \\
\hline L. granmongolense- $\mathrm{Hx}$ & $6.9 \pm 2.0 \mathrm{~b}$ & $5.1 \pm 1.6 \mathrm{~b}$ & $4.4 \pm 2.1 \mathrm{c}$ & $-67.6 \pm 10.7$ & $\mathrm{D}$ \\
\hline M. glomerata-Et & $4.7 \pm 2.0 \mathrm{~b}$ & $5.0 \pm 2.2 \mathrm{~b}$ & $3.9 \pm 0.9 \mathrm{c}$ & $-70.9 \pm 10.7$ & $\mathrm{D}$ \\
\hline L. ericoides-Et & $5.7 \pm 1.3 \mathrm{~b}$ & $6.6 \pm 1.6 \mathrm{~b}$ & $3.7 \pm 1.2 \mathrm{c}$ & $-71.8 \pm 10.7$ & $\mathrm{D}$ \\
\hline T. catigua-Hx & $4.7 \pm 0.7 b$ & $4.0 \pm 0.8 \mathrm{~b}$ & $3.7 \pm 1.2 \mathrm{c}$ & $-72.2 \pm 10.7$ & $\mathrm{D}$ \\
\hline L. salicifolia-Et & $6.3 \pm 1.4 \mathrm{~b}$ & $5.3 \pm 1.2 b$ & $2.6 \pm 0.7 \mathrm{c}$ & $-79.5 \pm 10.7$ & $\mathrm{D}$ \\
\hline A. indica-Hx & $1.5 \pm 0.6 \mathrm{~b}$ & $1.7 \pm 0.5 \mathrm{~b}$ & $1.5 \pm 0.9 \mathrm{c}$ & $-87.4 \pm 10.7$ & $\mathrm{D}$ \\
\hline A. indica- $\mathrm{Cl}$ & $3.1 \pm 0.8 \mathrm{~b}$ & $1.3 \pm 0.5 \mathrm{~b}$ & $0.9 \pm 0.4 \mathrm{c}$ & $-92.6 \pm 10.7$ & $\mathrm{D}$ \\
\hline $\mathrm{F}$ & $2.08^{*}$ & $2.45^{*}$ & $2.39^{*}$ & --- & --- \\
\hline $\mathrm{CV}(\%)$ & 81.42 & 79.55 & 81.91 & -- & --- \\
\hline
\end{tabular}

${ }^{1}$ Extracts: $\mathrm{Hx}=$ hexanic; $\mathrm{Cl}=$ chloroformic; $\mathrm{Et}=$ ethanolic; ${ }^{2}$ Means followed by the same letter in the column do not differ by Scott Knott's test $(\mathrm{p} \geq 0.05) ;{ }^{3}$ Oviposition preference index: OPI $=[(\mathrm{T}-\mathrm{C}) /(\mathrm{T}+\mathrm{C})] \mathrm{x} 100$, where $\mathrm{T}=$ extract evaluated and $\mathrm{P}=$ standard or control. OPI ranges from +100 for very stimulating $(\mathrm{S}), 0$ for neutral $(\mathrm{N})$ up to -100 for very deterrent $(\mathrm{D})$. 
granmongolense - ethanol (LG-Et) (9.9) and T. pallida - ethanol (TP-Cl) (10.0) $(F=2.45 ; \mathrm{df}=33,132 ; P=0.0002)$, which differed from the control that maintained the highest adult mean (26.3) and the other treatments (Table 1).

A significant reduction in the number of $B$. tabaci adults was observed when tomato leaflets were sprayed with aqueous extracts $(2 \% \mathrm{w} / \mathrm{v})$ from seeds of A. indica and leaves and branches of $T$. pallida compared to the control (Baldin et al., 2007b). The results obtained with Meliaceae in this work corroborate previous studies, where higher rates of repellency were observed in adults after $48 \mathrm{~h}$ of spraying tomato leaflets with leaves + branches of $M$. azedarach and T. pallida, leaves + seed extracts of $A$. indica, leaves of Mentha pulegium and seeds of Piper nigrum (Baldin et al.,

Table 2. Mean $( \pm \mathrm{SE})$ mortality of nymphs, viability and incubation period of Bemisia tabaci biotype B after application of Trichilia pallida, chloroform extract, at different concentrations. ( $\mathrm{T}=25 \pm 2^{\circ} \mathrm{C}$; UR $=65 \pm 10 \%$; photoperiod 14h). Botucatu, UNESP, 2012.

\begin{tabular}{|c|c|c|c|c|c|c|}
\hline \multirow{2}{*}{$\begin{array}{l}\text { Treatment TP- } \\
\mathrm{Cl}(\%)^{2}\end{array}$} & \multicolumn{3}{|c|}{ Mortality of nymphs ${ }^{1}(\%)$} & \multicolumn{2}{|c|}{ Viability of eggs ${ }^{1}(\%)$} & \multirow{2}{*}{$\begin{array}{c}\text { Incubation } \\
\text { period (days) }\end{array}$} \\
\hline & 1 DAA & 3 DAA & 7 DAA & 7 DAA & 10 DAA & \\
\hline 3.0 & $100.0 \pm 0.0 \mathrm{a}$ & $100.0 \pm 0.0 \mathrm{a}$ & $100.0 \pm 0.0 \mathrm{a}$ & $16.7 \pm 3.3 b$ & $28.9 \pm 8.7 \mathrm{c}$ & $7.0 \pm 0.2 \mathrm{a}$ \\
\hline 2.0 & $97.8 \pm 1.1 \mathrm{a}$ & $100.0 \pm 0.0 \mathrm{a}$ & $100.0 \pm 0.0 \mathrm{a}$ & $34.4 \pm 9.7 b$ & $37.8 \pm 6.8 \mathrm{c}$ & $5.9 \pm 0.3 \mathrm{a}$ \\
\hline 1.5 & $93.3 \pm 3.3 \mathrm{a}$ & $100.0 \pm 0.0 \mathrm{a}$ & $100.0 \pm 0.0 \mathrm{a}$ & $33.3 \pm 3.3 b$ & $50.0 \pm 3.8 \mathrm{c}$ & $6.4 \pm 0.5 \mathrm{a}$ \\
\hline 1.0 & $81.1 \pm 6.7 \mathrm{~b}$ & $100.0 \pm 0.0 \mathrm{a}$ & $100.0 \pm 0.0 \mathrm{a}$ & $66.7 \pm 8.8 \mathrm{a}$ & $86.7 \pm 8.4 \mathrm{a}$ & $6.6 \pm 0.4 \mathrm{a}$ \\
\hline 0.5 & $73.3 \pm 8.4 b$ & $95.6 \pm 2.2 \mathrm{a}$ & $100.0 \pm 0.0 \mathrm{a}$ & $61.1 \pm 11.3 \mathrm{a}$ & $64.4 \pm 9.5 b$ & $5.4 \pm 0.2 \mathrm{a}$ \\
\hline 0.1 & $57.8 \pm 8.0 \mathrm{c}$ & $80.0 \pm 6.7 b$ & $91.1 \pm 4.4 \mathrm{~b}$ & $67.8 \pm 10.9 \mathrm{a}$ & $70.0 \pm 10.2 b$ & $6.2 \pm 0.2 \mathrm{a}$ \\
\hline Control - acetone & $0.0 \pm 0.0 \mathrm{~d}$ & $1.1 \pm 1.1 \mathrm{c}$ & $12.2 \pm 2.9 \mathrm{c}$ & $76.7 \pm 12.0 \mathrm{a}$ & $100.0 \pm 0.0 \mathrm{a}$ & $6.3 \pm 0.3 \mathrm{a}$ \\
\hline Control - water & $0.0 \pm 0.0 \mathrm{~d}$ & $0.0 \pm 0.0 \mathrm{c}$ & $0.0 \pm 0.0 \mathrm{~d}$ & $92.2 \pm 7.8 \mathrm{a}$ & $100.0 \pm 0.0 \mathrm{a}$ & $4.8 \pm 0.8 \mathrm{a}$ \\
\hline $\mathrm{F}$ & $70.62^{*}$ & $315.27^{*}$ & $521.41^{*}$ & $8.04^{*}$ & $14.79^{*}$ & $2.74^{*}$ \\
\hline CV $(\%)$ & 13.51 & 6.04 & 4,33 & 27.73 & 18.21 & 11.73 \\
\hline
\end{tabular}

${ }^{1}$ Means followed by the same letter in the column do not differ by Scott Knott's test ( $\left.\mathrm{p} \geq 0.05\right)$; For statistical analysis, the data were transformed to $\operatorname{arc} \sin (\mathrm{x}+0.5) 1 / 2 ;{ }^{2} \mathrm{TP}-\mathrm{Cl}=$ chloroform extract of Trichilia pallida ${ }^{3} \mathrm{DAA}=$ days after application.

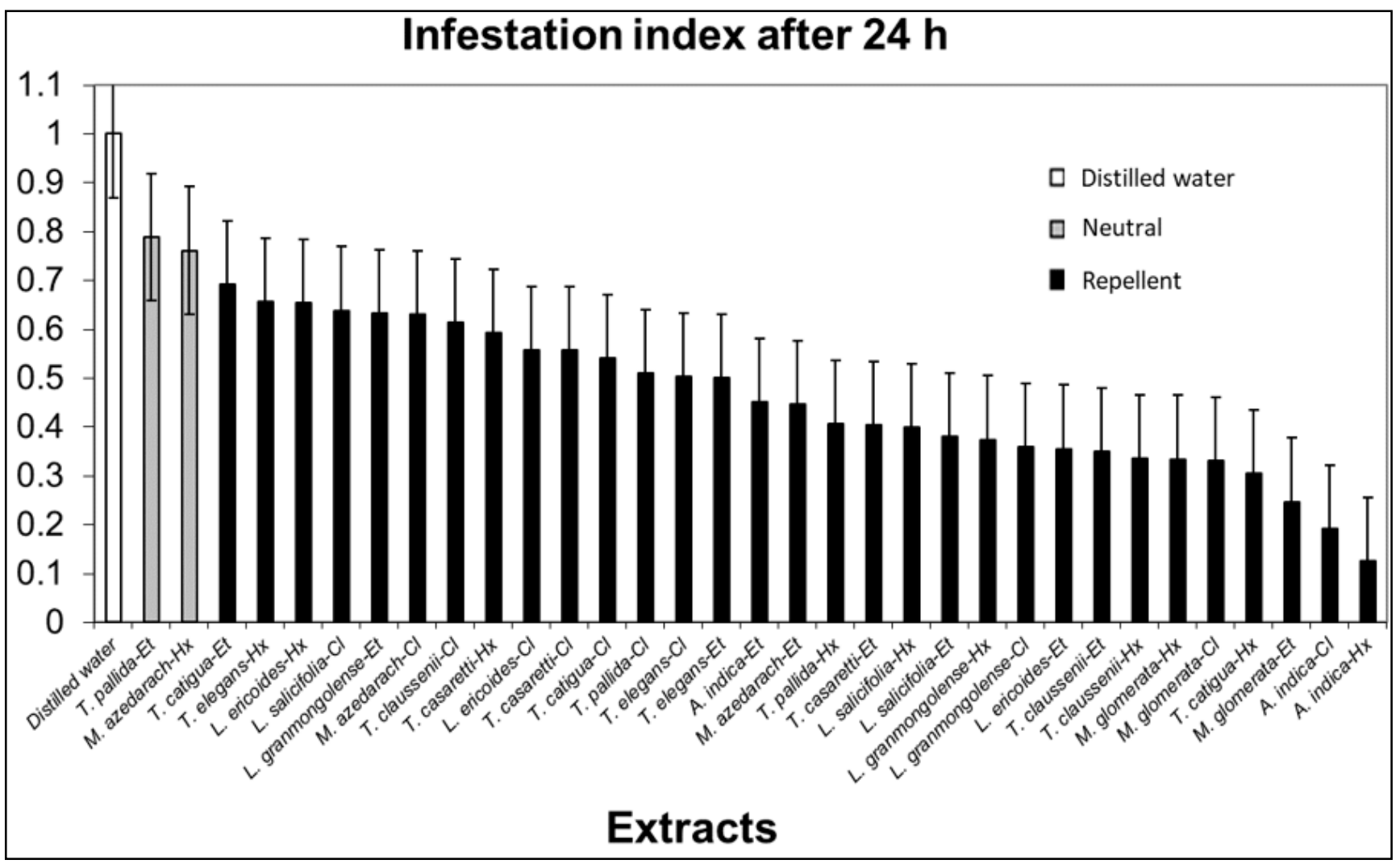

Figure 1. Infestation index of $\mathrm{B}$. tabaci biotype $\mathrm{B}$ on tomato leaflets $24 \mathrm{~h}$ after spraying; Extracts: $\mathrm{Hx}=\mathrm{hexanic} ; \mathrm{Cl}=\mathrm{chloroformic}$; Et= ethanolic; Classification: $\mathrm{N}=$ Neutral, comprising within classification interval $(\mathrm{CIi}<\mathrm{II}<\mathrm{CIs})$; I= Inhibitor or repellent (II $<\mathrm{CIi})$; $\mathrm{S}=\mathrm{Stimulant}$ (II $>$ CIs). $\left(\mathrm{T}=25 \pm 2^{\circ} \mathrm{C} ; \mathrm{UR}=65 \pm 10 \%\right.$; photoperiod $14 \mathrm{~h}$ ). Botucatu, UNESP, 2012. 
2007a). Based on the infestation rates obtained from the $B$. tabaci adult counts, all extracts were classified as repellent in the two evaluations, except for TP-Et and MA-Hx, which were neutral in the first evaluation (Figures 1 and 2).

Spraying with botanical derivatives from species of the genus Trichilia can make tomato plants less favorable to B. tabaci biotype B infestation and/ or colonization due to the presence of secondary metabolites that negatively influence the behavior of whitefly adults, thus reducing the number of insects in treated plants (Baldin et al., 2015).

It should be emphasized that in case of $B$. tabaci biotype B in tomato, the repellent effect of an extract may be of great importance, since preventing the insect from inhabiting the plant also prevents the insect from feeding on the plant and contaminating the plant with geminiviruses.

In general, the bioactivity of $A$. indica derivatives in insect control is due to the presence of different metabolites, especially limonoids, with triterpenoid azadirachtin being the major active component (Ley et al., 1993; Kusari et al., 2012). Limonoids can lead to dietary inhibition, reduced fecundity and cellular abnormalities, until mortality is achieved at different stages of insect development (Martinez, 2011). There are several reports on the bioactive properties of species belonging to the genus Trichilia. For example, in $T$. pallida, at least five tetraterpenoids have already been described with bioactivity (Simmonds et al., 2001). In Asteraceae, triterpenes and steroids are the second most-abundant secondary metabolites (Lean et al., 2009).

Lower oviposition was observed in the AI-Cl $\left(0.9\right.$ eggs $\left./ \mathrm{cm}^{2}\right)$, AI-Hx (1.5), LS-Et (2.6), TCat-Hx (3.7), LE-Et (3.7), MG-Et (3.9), LG-Hx (4.4), TCas-Et (4.5), TP-Cl (4.8), LG-Cl (4.8), $T$. casaretti - hexane (TCas-Hx) (5.0), L. salicifolia - hexane (LS-Hx) (5.0), T. pallida - hexane (TP-Hx) (5.0), $M$. azedarach MA-Et (5.5), T. clausenii - chloroform (TCla-Cl) (5.5), MG-Cl (6.3), TCla-Hx (6.3), TE-Et (6.6), LG-Et (6.8), LE-Cl (7.3), Mg-Hx (7.4), TCat$\mathrm{Cl}$ (7.5), TE-Cl (7.9), AI-Et (7.9), TClaEt (8.1) and TP-Et (8.2) treatments $(F$ $=2.39 ; \mathrm{df}=33,132 ; P=0.0002)$; these differed significantly from treatment with distilled water (22.7) (Table 1).

Among the plants of the family Meliaceae, A. indica presented a greater range of results regarding its effects on the behavior of $B$. tabaci (Baldin et al., 2015). The reduction of insect oviposition in response to these extracts suggests that they contain volatile compounds that are deterrent to oviposition and that these extracts prevent the insect from continuing to oviposit in treated locations due to the presence of adverse factors (Baldin et al., 2019).

Based on the averages of oviposition, all extracts were classified as deterrent to the oviposition of $B$. tabaci biotype B (Table 1). Given that all treatments were repellent after $48 \mathrm{~h}$ of application (Figure 2), the possible deterrence in insect oviposition was also expected, once this behavior (attraction followed by oviposition) occurs to several insect species (Kogan, 1975).

In previous studies, aqueous extracts based on leaves + branches of $M$. azedarach, Tagetes erecta, Ricinus communis, leaves of Menta pulegium, T. pallida, A. indica and seeds of Piper nigrum were considered deterrent (Baldin et al., 2007a).

Bioactivity and estimated $\mathrm{LC}_{50}$ from T. pallida - chloroform

In relation to the nymphicidal effect of the TP-Cl extracts (Table 2),

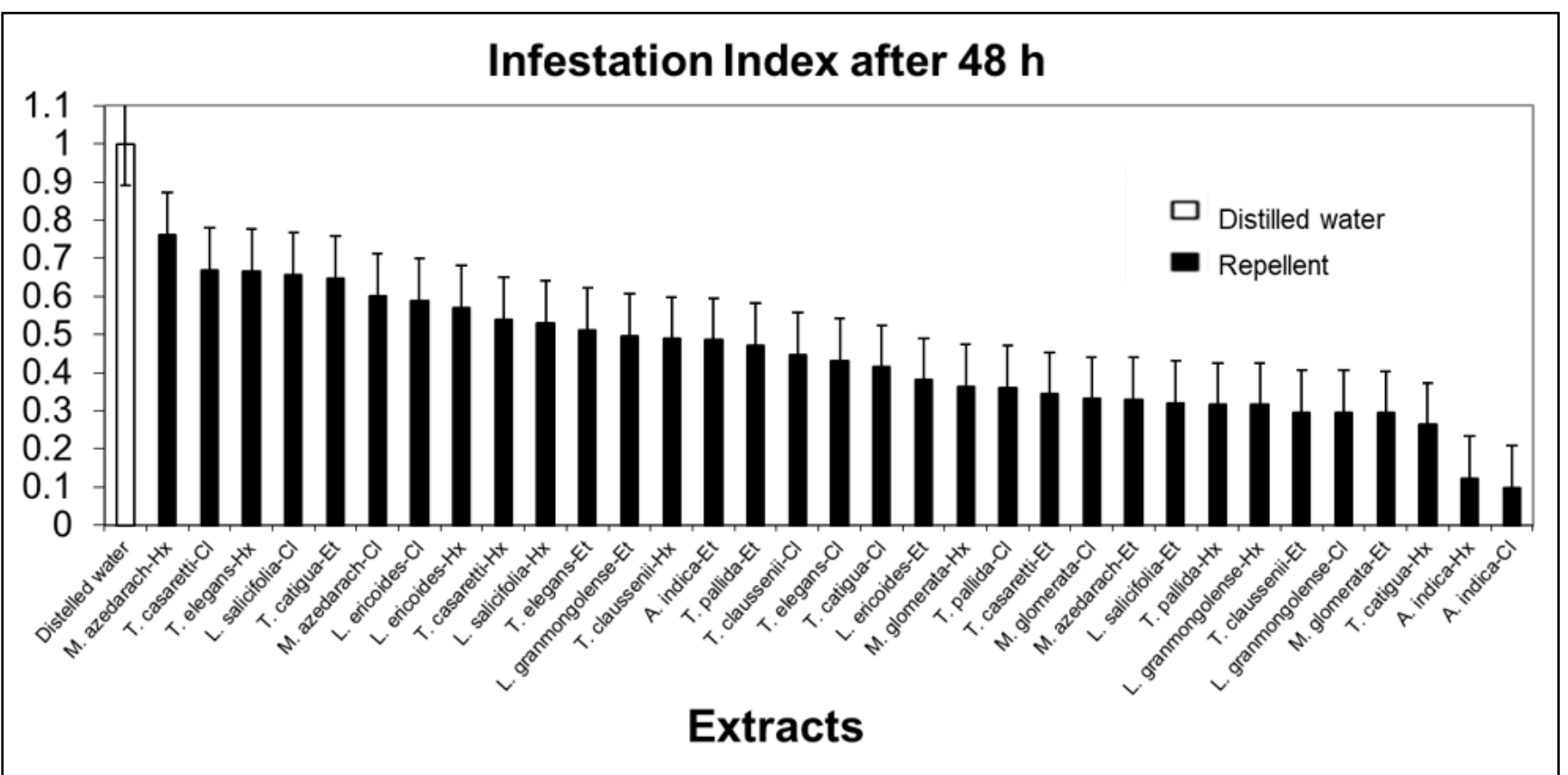

Figure 2. Infestation index of B. tabaci biotype $\mathrm{B}$ on tomato leaflets $48 \mathrm{~h}$ after spraying; Extracts: $\mathrm{Hx}=\mathrm{hexanic} ; \mathrm{Cl}=\mathrm{chloroformic}$; Et= ethanolic; Classification: $\mathrm{N}=$ Neutral, comprising within classification interval $(\mathrm{CIi}<\mathrm{II}<\mathrm{CIs}$ ); $\mathrm{I}=$ Inhibitor or repellent $(\mathrm{II}<\mathrm{CIi})$; $\mathrm{S}=\mathrm{Stimulant}$ (II $>$ CIs). $\left(\mathrm{T}=25 \pm 2^{\circ} \mathrm{C} ; \mathrm{UR}=65 \pm 10 \%\right.$; photoperiod $\left.14 \mathrm{~h}\right)$. Botucatu, UNESP, 2012. 
all concentrations were efficient in the control of whitefly one day after application (1 DAA), and differing from the controls, which did not cause mortality of the nymphs. At three days after application (3 DAA), the four highest concentrations of the extract caused $100 \%$ nymphal mortality. At seven days after application (7 DAA), the results indicate that the TP-Cl extract, even at the lowest concentration, shows high efficiency $(91.1 \%)$ in the control of whitefly nymphs, evidencing the potential for the alternative control of $B$. tabaci biotype B in tomato.

In other studies, the use of ethanolic extract at $0.56 \%(\mathrm{w} / \mathrm{v})$ of leaves of $T$. pallida caused $86.96 \%$ mortality of nymphs, and the extract in dichloromethane caused $73.19 \%$ mortality at 7 DAA (Bezerra-Silva et al., 2010). These results were lower than those obtained in this study in which $100 \%$ mortality was verified at 7 DAA from the application of the $0.5 \%$ TP-Cl extract.

The estimated $\mathrm{LC}_{50}$ for nymphs of $\mathrm{B}$. tabaci biotype $\mathrm{B}$ one day after application of the TP-Cl extract was $0.0955 \%$ (95\% confidence interval; 0.007-0.237; slope $1.1 \pm 0.25$; chisquare test 36.28 ). Although there are no previous reports estimating the $\mathrm{LC}_{50}$ of extracts of T. pallida on this whitefly species, other authors (Roel et al., 2000) estimated an $\mathrm{LC}_{50}$ equal to $0.048 \%$ with the ethyl acetate extract of T. pallida on Spodoptera frugiperda (Lepidoptera: Noctuidae) that were 7 days of age, evidencing the bioactivity of derivatives of this botanical species.

Regarding the viability of the eggs (Table 2), at 7 DAA, the 3.0, 2.0 and $1.5 \% \mathrm{TP}-\mathrm{Cl}$ extracts caused the lowest viability (16.7, 34.4 and $33.33 \%$ ), differing significantly from controls (water $=92.2 \%$ and acetone $=76.7 \%$ ). At 10 DAA, the 3.0, 2.0 and 1.5\% TP-Cl extracts provided the lowest egg-hatching mean values $(28.9,37.8$ and $50.0 \%$ ), differing from that of the controls, which allowed all the eggs of B. tabaci biotype B to hatch. At the highest concentration of the extract, the average incubation period increased in relation to the water control, although the treatments did not differ statistically from each other.

Trials aiming to evaluate the ovicidal effect of $3 \%(\mathrm{w} / \mathrm{v})$ aqueous extracts of Meliaceae on B. tabaci biotype B reported mortality rates of $38.65 \%$ for $T$. pallida, followed by $A$. indica $(31.31 \%)$, $M$. azedarach $(28.91 \%)$ and control $(2.15 \%)$ treatment; and also, there was no difference among treatments in the mean time needed for hatching of nymphs (Souza \& Vendramim, 2000).

In general, infestation and oviposition tests demonstrated the bioactivity of some Meliaceae ( $A$. indica and Trichilia spp.) and Asteraceae (Lychnophora spp.) plants and their respective fractions in the reduction of the insect population. The nymphicidal and ovicidal effects verified with $T$. pallida extracts (TP-Cl), reinforce the potential of botanical derivatives of this species and corroborate the findings of other studies (Gonçalves-Gervásio \& Vendramin, 2004).

Although much research is still needed, mainly with the aim of isolating the major compounds from the extracts, the results indicate a great potential for these botanical species, since the chloroform extract of $T$. pallida, even at the lowest concentration tested, showed $91.1 \%$ in the control of whitefly nymphs and only $28.9 \%$ in egg-hatching at the highest concentration (3\%) added to a low rate of infestation by adults and low oviposition in the previous trial.

It should be noted that due to the complexity of mixtures involving botanical derivatives, the use of these extracts causes a lower selection pressure on pests in crops and decreases the development of resistance in the target insects with positive impacts implicated for Integrated Pest Management (IPM).

\section{ACKNOWLEDGMENTS}

The authors are grateful to the Brazilian Foundations FAPESP (Proc. 2007/50688-8) and CNPq (Proc. 303892/2016-1) for grants and fellowships.

\section{REFERENCES}

ABOU-FAKHR HAMMAD, EM; ZEAITER,
A; SALIBA, N; TALHOUK, S. 2014. Bioactivity of indigenous medicinal plants against the cotton whitefly, Bemisia tabaci Journal of Insect Science 14: 105.

BALDIN, ELL; FANELA, TLM; PANNUTI, LER; KATO, MJ; TAKEARA, R; CROTTI, AEM. 2015. Botanical extracts: alternative control for silver leaf whitefly management in tomato. Horticultura Brasileira 33: 59-65.

BALDIN, ELL; SOUZA, DR; SOUZA, ES; BENEDUZZI, RA. 2007a. Controle de mosca-branca com extratos vegetais em tomateiro em casa de vegetação. Horticultura Brasileira 25: 602-606.

BALDIN, ELL; VENDRAMIM, JD; LOURENÇÃO, AL. 2005. Resistance of tomato genotypes to the whitefly Bemisia tabaci (Gennadius) biotype B (Hemiptera: Aleyrodidae). Neotropical Entomology 34: 434-441.

BALDIN, ELL; VENDRAMIM, JD; LOURENÇÃO, AL. 2007b. Interaction between resistant tomato genotypes and plant extracts on Bemisia tabaci (Genn.) biotype B. Scientia Agricola 64: 476-481.

BALDIN, ELL; VENDRAMIM, JD; LOURENÇÃO, AL. 2019. Resistência de plantas a insetos - fundamentos e aplicações. Piracicaba: FEALQ. 493p.

BEZERRA-SILVA, GCD; SILVA, MA; VENDRAMIM, JD; DIAS, CT. 2012. Insecticidal and behavioral effects of secondary metabolites from Meliaceae on Bemisia tabaci (Hemiptera: Aleyrodidae). Florida Entomologist 95: 743-751.

BEZERRA-SILVA, GCD; VENDRAMIM, JD; SILVA, MA; DIAS, CT. 2010. Efeito de extratos orgânicos de Meliaceae sobre Bemisia tabaci (Gennadius) biótipo B em tomateiro. Arquivos do Instituto Biológico 77: 477-485.

DÂNGELO, RAC; MICHEREFF-FILHO, M; CAMPOS, MR; SILVA, PS; GUEDES, RNC. 2018. Insecticide resistance and control failure likelihood of the whitefly Bemisia tabaci (MEAM1; B biotype): a Neotropical scenario. Annals of Applied Biology 172: 88-99.

DE BARRO, PJ; LIU, SS; BOYKIN, LM; DINSDALE, AB. 2011. Bemisia tabaci: A statement of species status. Annual Review of Entomology 56: 1-19.

DE BARRO, PJ; SCOTT, KD; GRAHAM, GC; LANGE, CL; SCHUTZE, MK. 2003. Isolation and characterization of microsatellite loci in Bemisia tabaci. Molecular Ecology Notes 3: 40-43.

FIRDAUS, S; HEUSDEN, AW; HIDAYATI, N; SUPENA, EDJ. 2012. Resistance to Bemisia tabaci in tomato wild relatives. Euphytica 187: 31-45.

G ON Ç A LVE S-GERV Á S I O, R C R ; VENDRAMIM, JD. 2004. Modo de ação de extratos de meliáceas sobre Tuta absoluta (Meyrick, 1917) (Lepidoptera: Gelechiidae). Arquivos do Instituto Biológico 71: 215-220.

GRAEL, CFF; KANASHIRO, A; KABEVA, LM; JORDÃO, CO; TAKEARA, R; GOBBO NETO, L; POLIZELLO, ACM; LUCISANOVALIM, YM; LOPES, NP; LOPES, JLC. 2010. In vitro study of antioxidant and 
scavenger properties of phenolic compounds from Lychnophora species. Quimica Nova 33: 867-870.

HANSSEN, IM; LAPIDOT, M; THOMMA, BPH. 2010. Emerging viral diseases of tomato crops. Molecular Plant-Microbe Interactions 23: $539-548$.

INOUE-NAGATA, AK; CARVALHO, CM; ZERBINI, FM; REZENDE, JAM; SAKATE, RK; NAGATA, T. 2016. Vírus transmitidos por moscas-brancas no Brasil: vetores, principais doenças e manejo. Revisão Anual de Patologia de Plantas 24: 7-29.

KOGAN, M. 1975. Plant resistance in pest management. In: METCALF, RL; LUCKMANN, WH (eds). Introduction to insect pest management. John Wiley \& Sons, New York, NY, USA. p.103-146.

KUSARI, S; VERMA, VC; LAMSHOEFT, M; SPITELLER, M. 2012. An endophytic fungus from Azadirachta indica A. Juss. that produces azadirachtin. World Journal of Microbiology and Biotechnology 28: 1287-1294.

LEAN, S; RICHARDS, SM; COVER, SL; BRANDON, S; DAVIES, NW; BRYANT, JP; CLAUSEN, TP. 2009. Papyriferic acid, an antifeedant triterpene from birch trees, inhibits succinate dehydrogenase from liver mitochondria. Journal of Chemical Ecology 35: 1252-1261.

LEORA SOFTWARE. 2003. POLO-Plus 1.0 Probit and Logit analysis. Petaluma: LeOra Software.

LEY, SV; DENHOM, AA; WOOD, A. 1993. The chemistry of azadirachtin. Natural Product Reports 10: 109-157.
MARTINEZ, SS. 2011. O nim: Azadirachta indica - natureza, usos múltiplos, produção. Londrina: Instituto Agronômico do Paraná. $142 \mathrm{p}$.

MUSABYIMANA, T, SAXENA, R; KAIRU, E; OGOL, C; KHAN, Z. 2001. Effects of neem seed derivatives on behavioral and physiological responses of the Cosmopolites sordidus (Coleoptera: Curculionidae). Journal of Economic Entomology 94:449-454.

RAIJ, B; CANTARELLA, H; QUAGGIO, JA; FURLAN, AMC. 1997. Recomendações de adubação e calagem para o estado de São Paulo (Boletim Técnico 100). Campinas: Fundação IAC. 285p.

ROEL, AR; VENDRAMIM, JD; FRIGHETTO, RTS; FRIGHETTO, N. 2000. Efeito do extrato acetato de etila de Trichilia pallida Swartz (Meliaceae) no desenvolvimento e sobrevivência da lagarta-do-cartucho. Bragantia 59: 53-58.

ROJAS, MR; MACEDO, MA; MALIANO, MR; SOTO-AGUILAR, M; SOUZA, JO; BRIDDON, RBW; KENYON, L; RIVERA BUSTAMANTE, RF; ZERBINI, FM; ADKINS, S; LEGG, JP; KVARNHEDEN, A; WINTERMANTEL, WM; SUDARSHANA, MR; PETERSCHMITT, M; LAPIDOT, M; MARTIN, DP; MORIONES, E; INOUENAGATA, AK; GILBERTSON, RL. 2018. World management of geminiviruses. Annual Review of Phytopathology 56: 637-677.

SAS INSTITUTE. 2001. SAS/STAT User's Guide, Version 8.1. North Carolina: SAS Institute, Cary.

SHADMANY, M; OMAR, D; MUHAMAD, R.
2015. Biotype and insecticide resistance status of Bemisia tabaci populations from Peninsular Malaysia. Journal of Applied Entomology 139: 67-75.

SILVA, MA; BEZERRA-SILVA, GCD; VENDRAMIM, JD; MASTRANGELA, T. 2012. Inhibition of oviposition by neem extract: a behavioral perspective for the control of the Mediterranean fruit fly (Diptera: Tephritidae). Florida Entomologist 95: 332336.

SIMMONDS, MSJ; STEVENSON, PC; PORTER, EA; VEITCH, NC. 2001. Insect antifeedant activity of new three tetranortriterpenoids from Trichilia pallida. Journal of Natural Products 64: 1117-1120.

SOUZA, AP; VENDRAMIM, JD. 2000. Efeito de extratos aquosos de meliáceas sobre Bemisia tabaci biótipo B em tomateiro. Bragantia 59: 173-179.

SRINIVASAN, R; RILEY, D; DIFFIE, S; SPARKS, A; ADKINS, S. 2012. Whitefly population dynamics and evaluation of whitefly transmitted Tomato yellow leaf curl virus (TYLCV) - resistant tomato genotypes as whitefly and TYLCV reservoirs. Journal of Economic Entomology 105: 1447-1456.

TAVARES, WS; CRUZ, I; PETACCI, F; ASSIS JUNIOR, SL; FREITAS, SS; ZANUNCIO, JC; SERRÃO, JE. 2009. Potential use of Asteraceae extracts to control Spodoptera frugiperda (Lepidoptera: Noctuide) and selectivity to their parasitoids Trichogramma pretiosum (Hymenoptera: Trichogrammatidae) and Telenomus remus (Hymenoptera: Scelionidae) Industrial Crops and Products 30: $384-388$. 